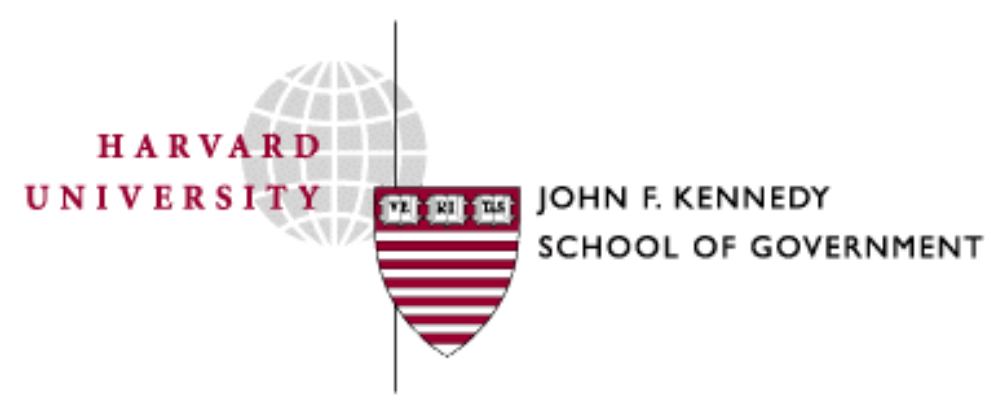

Faculty Research Working Papers Series

\title{
An International Architecture for the Post-Kyoto Era
}

\section{Sheila M. Olmstead and Robert N. Stavins}

\section{March 2006 \\ RWP06-009}

This paper can be downloaded without charge from:

http://ksgnotes1.harvard.edu/Research/wpaper.nsf/rwp/RWP06-009

or

The Social Science Research Network:

http://ssrn.com/abstract $=902371$

The views expressed in the KSG Faculty Research Working Paper Series are those of the author(s) and do not necessarily reflect those of the John F. Kennedy School of Government or Harvard University. Copyright belongs to the author(s). Papers may be downloaded for personal use only. 


\title{
An International Policy Architecture for the Post-Kyoto Era
}

\author{
Sheila M. Olmstead and Robert N. Stavins*
}

In February, 2005, the Kyoto Protocol to the United Nations Framework Convention on Climate Change came into force, but without participation by the United States. Its impacts on emissions of greenhouse gases - including carbon dioxide $\left(\mathrm{CO}_{2}\right)$, the primary anthropogenic driver of climate change — will be trivial; but scientific (Robert T. Watson 2001) and economic analyses (Charles D. Kolstad and Michael A. Toman 2001) point to the need for a credible international approach.

Because the Kyoto Protocol's ambitious targets apply only to the short term (2008-2012) and only to industrialized nations, the agreement will impose relatively high costs and generate only modest short-term benefits while failing to provide a real solution (Joseph E. Aldy et al. 2003). For these reasons, most economists see the agreement as deeply flawed (Richard N. Cooper 1998; David G. Victor 2001; Warwick J. McKibbin and Peter J. Wilcoxen 2002), although some see it as an acceptable first step (Axel Michaelowa 2003). Virtually all agree, however, that the Protocol is not sufficient to the overall challenge.

We describe the basic features of a post-Kyoto international global climate agreement, which addresses three crucial questions: who, when, and how. The respective elements are: first, a means to ensure that key nations — industrialized and developing — are involved; second, an emphasis on an extended time path of action (employing a cost-effective pattern over time); and third, inclusion of market-based policy instruments. 


\section{Who - Expand Participation to Include All Key Countries}

Broad participation, by major industrialized nations and key developing countries, is essential to address this global commons problem effectively and efficiently. Developing countries are likely to account for more than half of global emissions by 2020, possibly sooner (Nebojsa Nakicenovic and Robert Swart 2000). It can be argued, on an ethical basis, that industrialized countries should take the first steps, since — almost by definition — they are responsible for the bulk of anthropogenic concentrations of greenhouse gases in the atmosphere. But two serious problems remain. First, developing countries currently provide the greatest opportunities for lowcost emissions reductions (Watson 2001). Second, if developing countries are not included, comparative advantage in the production of carbon-intensive goods and services will shift outside the coalition of participating countries, pushing non-participating nations onto more carbonintensive growth paths, increasing their costs of joining the coalition later.

This poses a policy conundrum. On the one hand, for purposes of environmental effectiveness and economic efficiency, key developing countries should participate. On the other hand, for purposes of distributional equity (and international political pragmatism), they cannot be expected to incur the consequent costs. The answer is a set of "growth targets" that are set initially at business-as-usual (BAU) levels for respective developing countries, but become more stringent as those countries become more wealthy. This would be a natural extension of the allocation pattern in the Kyoto Protocol, where targets for industrialized countries exhibit an income elasticity of reductions of about 0.10 (Jeffrey A. Frankel 1999).

Initial targets for developing countries could even be set at emissions that are above BAU levels. If combined with an international trading program (discussed below), this would provide 
significant economic incentives for participation. Developing countries could fully participate without incurring prohibitive (or even any) costs in the short term. Cost-effectiveness and distributional equity would both be addressed.

\section{When - Use An Extended Time Path}

Global climate change is a long-term problem, because greenhouse gases remain in the atmosphere for decades to centuries, but the Kyoto Protocol fails to reflect this cumulative, stockpollutant nature of the problem. The Protocol's short-term targets, an average 5 percent reduction from 1990 levels by the 2008-2012 compliance period, may sound modest, but they translate into severe 25-30 percent cuts for the United States from its BAU path, because of the rapid economic growth the country enjoyed during the 1990s, amounting to a 37 percent increase in real gross domestic product (GDP).

Thus, the Kyoto Protocol's targets are too little, too fast: they do little about the problem, but are unreasonable for countries that experienced significant economic growth post-1990. Two elements will ameliorate this problem: moderate targets in the short term to avoid rendering large parts of the capital stock prematurely obsolete, and more stringent targets for the long term to motivate (now and in the future) technological change, in order to bring costs down over time.

Targets ought to begin at BAU levels, then depart gradually, so that emissions increase at first but at rates below BAU. These targets should reach a maximum level and then decrease eventually becoming much more severe than the constraints implied by the Kyoto Protocol's targets. This is consistent with estimates of the least-cost time path of emissions for achieving long-term greenhouse-gas concentration goals (Alan S. Manne and Richard G. Richels 1997). For example, 
for the frequently-discussed goal of stabilizing atmospheric concentrations of $\mathrm{CO}_{2}$ at twice preindustrial levels, the cost-effective time path of emissions would involve global emissions peaking in 2030 (Thomas M. L. Wigley et al. 1996). Of course, the long-term targets should be flexible, because there is great uncertainty throughout the policy-economics-biophysical system, some of which will be resolved over time (Richels et al. 2004).

We use the word "target" generically to refer not only to emission targets (as in the Kyoto Protocol) but also to "intensity targets" - emissions per unit of GDP. The proposal we offer is also consistent with a time-path of targets denominated in financial units, such as carbon prices (taxes on the carbon content of fossil fuels). In any event, this time path of targets - put in place now would also be consistent with what is often denigrated as "politics as usual." Politicians in representative democracies are frequently condemned because there are incentives to place greater costs on future, not current voters. It is typically the politically pragmatic strategy. In the case of global climate policy, it may also be the scientifically correct and economically rational approach.

\section{How — Employ Market-Based Policy Instruments}

All observers agree that conventional regulatory approaches cannot do the job, certainly not at acceptable costs. To keep costs down in the short term and bring them down even lower in the long term through technological change, it is essential to embrace market-based instruments.

On a domestic level, systems of tradable permits might be used to achieve national targets. This approach was used in the United States to phase out leaded gasoline in the 1980s at a savings of more than $\$ 250$ million per year over an equivalent traditional regulatory approach (Robert $\mathrm{N}$. Stavins 2003), and is now used to cut sulfur dioxide $\left(\mathrm{SO}_{2}\right)$ emissions from power plants by half, at 
an annual cost savings of $\$ 1$ billion (A. Denny Ellerman et al. 2000). The better policy model for climate change is the upstream lead-rights system (analogous to trading on the carbon content of fossil fuels), rather than the downstream $\mathrm{SO}_{2}$ emissions-trading system.

For some countries, systems of domestic carbon taxes may be more attractive, and a particularly promising approach is a hybrid of tax and tradable-permit systems — an ordinary tradable permit system, plus a government promise to sell additional permits at a stated price (McKibbin and Wilcoxen 2002; William A. Pizer 2002). This addresses cost uncertainty by creating a price (and thereby cost) ceiling, and has hence been labeled a safety-valve approach.

International policy instruments are also required, and the Kyoto Protocol includes a system whereby the parties to the agreement can trade their "assigned amounts" — their national reduction targets — translated into emissions terms. In theory, such a system of international tradable permits — if implemented only for the industrialized countries (as in the Protocol) — could reduce costs by 50 percent. If such a system were to include major developing countries as well, costs could be lowered to 25 percent of what they otherwise would be (James A. Edmonds et al. 1997).

A theoretical attraction of an international trading approach is that the equilibrium allocation of permits, the market-determined permit price, and the aggregate costs of abatement are independent of the initial allocation of permits among countries. This is only true if particularly unlikely types of transaction costs are not prevalent and individual parties — be they nations or firms - are not able to exercise market power. The latter concern is a real one in the climate policy context. If, for example, the majority of excess permits (allowable emissions in excess of BAU emissions) is found in a relatively small number of nations, then the possibility increases of collusion among sellers (Manne and Richels 2004). Furthermore, an international trading system 
must be designed to facilitate integration with domestic policies, because individual nations' choices of domestic policy instruments can substantially limit the cost-saving potential of an international system (Robert W. Hahn and Stavins 1999).

In any event, the initial allocation of permits among nations can imply exceptionally large international wealth transfers. Several analysts have identified this as a major objection to an international carbon trading regime, and have endorsed international tax approaches for this and other reasons (Cooper 1998; McKibbin and Wilcoxen 2002; Pizer 2002; Richard G. Newell and Pizer 2003; and William D. Nordhaus 2005). Many of the objections are well-founded, but it is the wealth-transfer feature of the permit approach that allows cost-effectiveness and distributional equity to be addressed simultaneously.

\section{Conclusions}

The three-part global climate policy architecture we propose can form the foundation for a successor to the Kyoto Protocol. For such an approach to work, key nations must be involved, including major developing countries through the use of economic trigger mechanisms such as growth targets. In addition, cost-effective time paths of targets are required: firm, but moderate in the short term, and in the long term, much more stringent yet flexible. Finally, market-based policy instruments ought to be part of the package, whether emissions trading, carbon taxes, or hybrids of the two.

A premise of our proposal is that the global commons nature of the climate problem requires a multinational — if not fully global — approach. As long as global marginal benefits exceed every nation's own marginal benefits, countries will either want to avoid participating or avoid complying 
fully if they do participate. Successful international cooperation must change these incentives (Scott Barrett and Stavins 2003). Can countries credibly commit to the long-term program that is part of this proposed architecture? Our answer is that once nations have ratified the agreement, implementing legislation within respective nations would translate the agreed long-term targets into domestic policy commitments. And once such implementing legislation was enacted, signals would thereby be sent to private industry, which would begin to take action. Ultimately, such domestic actions provide the signals that other countries need to see. This represents a logical and ultimately feasible chain of credible commitment.

This overall approach can be made to be scientifically sound, economically rational, and politically pragmatic. There is no denying that the challenges facing adoption and successful implementation of this climate policy architecture are significant, but they are no greater than the challenges facing other approaches to the threat of global climate change.

\section{REFERENCES}

Aldy, Joseph E.; Barrett, Scott and Stavins, Robert N. “Thirteen Plus One: A Comparison of Global Climate Policy Architectures.” Climate Policy, 2003, 3(4), pp. 373-97.

Barrett, Scott and Stavins, Robert N. "Increasing Participation and Compliance in International Climate Change Agreements.” International Environmental Agreements: Politics, Law and Economics, December 2003, 3(4), pp. 349-76.

Cooper, Richard N. “Toward a Real Treaty on Global Warming.” Foreign Affairs, March/April 1998, 77(2), pp. 66-79. 
Edmonds, J. A.; Kim, S. H.; MacCracken, C. N.; Sands, R. D. and Wise, M. A. Return to 1990: The Cost of Mitigating United States Carbon Emissions in the Post-2000 Period. Washington, DC: Pacific Northwest National Laboratory, operated by Battelle Memorial Institute, 1997. Ellerman, A. Denny; Joskow, Paul L.; Schmalensee, Richard; Montero, Juan-Pablo and Bailey, Elizabeth M. Markets for Clean Air: The U.S. Acid Rain Program. New York: Cambridge University Press, 2000.

Frankel, Jeffrey A. “Greenhouse Gas Emissions.” Policy brief no. 52, Brookings Institution, 1999. Hahn, Robert W. and Stavins, Robert N. What Has the Kyoto Protocol Wrought? The Real Architecture of International Tradable Permit Markets. Washington, DC: American Enterprise Institute Press, 1999.

Kolstad, Charles D. and Toman, Michael A. “The Economics of Climate Policy,” in Karl-Goran Mäler and Jeffrey Vincent, eds., Handbook of Environmental Economics, Volume II. Amsterdam: Elsevier Science, forthcoming.

Manne, Alan S. and Richels, Richard G. "On Stabilizing $\mathrm{CO}_{2}$ Concentrations - Cost-Effective Emission Reduction Strategies.” Environmental Modeling and Assessment, December 1997, 2(4), pp. 251-265.

. "U.S. Rejection of the Kyoto Protocol: The Impact on Compliance Costs and $\mathrm{CO}_{2}$ Emissions.” Energy Policy, March 2004, 32(4), pp. 447-54.

McKibbin, Warwick J. and Wilcoxen, Peter J. “The Role of Economics in Climate Change Policy.” Journal of Economic Perspectives, Spring 2002, 16(2), pp.107-29.

Michaelowa, Axel. “Global Warming Policy.” Journal of Economic Perspectives, Summer 2003, 17(3), pp. 204-05. 
Nakicenovic, Nebojsa and Swart, Robert, eds., Intergovernmental Panel on Climate Change Special Report on Emissions Scenarios. Cambridge, United Kingdom: Cambridge University Press, 2000.

Newell, Richard G. and Pizer, William A. "Regulating Stock Externalities Under Uncertainty.” Journal of Environmental Economics and Management, March 2003, 45(2S), pp. 416-32.

Nordhaus, William D. “Economic Analyses of Kyoto Protocol: Is There Life After Kyoto?” Conference paper presented at “Global Warming: Looking Beyond Kyoto,” Yale University, New Haven, Connecticut, October 21-22, 2005.

Pizer, William A. “Combining Price and Quantity Controls to Mitigate Global Climate Change.” Journal of Public Economics, September 2002, 85(3), pp. 409-34.

Richels, Richard G.; Manne, Alan S. and Wigley, Thomas M. L. "Moving Beyond Concentrations — The Challenge of Limiting Temperature Change.” Working paper no. 04-11, AEIBrookings Joint Center for Regulatory Studies, 2004.

Stavins, Robert N. "Experience with Market-Based Environmental Policy Instruments,” in KarlGoran Mäler and Jeffrey Vincent, eds., Handbook of Environmental Economics, Volume I. Amsterdam: Elsevier Science, 2003, pp. 355-435.

. “Forging a More Effective Global Climate Treaty.” Environment, December 2004, 46(10), pp. 23-30.

Victor, David G. The Collapse of the Kyoto Protocol and the Struggle to Slow Global Warming. Princeton, New Jersey: Princeton University Press, 2001. 
Watson, Robert T., ed., Climate Change 2001: Synthesis Report. Contributions of Working Group I, II, and III to the Third Assessment Report of the Intergovernmental Panel on Climate Change. Cambridge, UK: Cambridge University Press, 2001.

Wigley, Thomas M. L.; Richels, Richard G. and Edmonds, Jae. "Economic and Environmental Choices in the Stabilization of Atmospheric $\mathrm{CO}_{2}$ Concentrations.” Nature, 18 January 1996, 379(6562), pp. 240-43.

\section{FOOTNOTES}

*Olmstead: School of Forestry and Environmental Studies, Yale University, 230 Prospect Street, New Haven, Connecticut 06511 (e-mail: sheila.olmstead@yale.edu); Stavins: John F. Kennedy School of Government, Harvard University, 79 John F. Kennedy Street, Cambridge, Massachusetts 02138, and Resources for the Future (e-mail: robert_stavins@harvard.edu). Further details are available in Stavins (2004). We have benefitted from helpful discussions with Jeffrey Frankel and David Victor. 